\title{
THE EFFECT OF WORK STRESS ON THE PERFORMANCE OF EMPLOYEES PSYCHOLOGYCAL WELL-BEING AND SUBJECTIVE WELL-BEING (Study at PT. Global Insight Utama Bali Area)
}

\section{Ekromi Fraida Tsalasah \\ Faculty of Economics and Business, \\ University of Brawijaya, \\ Malang, Indonesia, \\ ekromifraida@yahoo.com}

\section{Noermijati,}

Faculty of Economics and

Business,

University of Brawijaya,

Malang, Indonesia,

Kusuma Ratnawati

Faculty of Economics and Business,

University of Brawijaya,

Malang, Indonesia

\begin{abstract}
This study aimed to analyze the effect of work stress on employee performance, analyze the effect of work stress on psychologically well-being, to analyze the influence of psychological the well-being of the employee's performance, analyze the effect of work stress on subjective well-being, to analyze the influence of subjective wellbeing of the performance employee, psychological To analyze the effect of well-being as mediation work stress on employee performance and analyze the influence of subjective well-being as mediation work stress on employee performance. Mechanical analysis using PLS. The analysis showed that the effect of work stress on employee performance, job stress affect the well-being psychological, psychological well-being affect the performance of the employee.
\end{abstract}

Keywords: Job Stress, Psychological Well-Being, Subjective WellBeing, Employee Performance

\section{INTRODUCTION}

Performance is the real behavior generated by each person as the resulting performance by employees in accordance with its role within the company (Riva, 2004: 309). To get good performance of an employee of an organization must be able to provide the facilities and infrastructure to support the work REMEDY. One way in which to view the development of the company is by looking at the results of performance appraisal. Means that form the object of the performance appraisal is a skill. The ability of employees to carry out a job or task that is evaluated by using a specific benchmark for objectively and done regularly. From the assessment results can be seen in the company's performance, as reflected by the performance of employees.

Good job performance is one of the objectives of the organization in achieving high productivity. Campbell, et al. in Umam (2010: 186) states that the performance as something that looks, that is relevant to your individual organizational objectives. A person's performance is a combination of ability, effort, and opportunity that can be measured from the effects it produces. Therefore, the performance of not involving personal characteristics exhibited by a person through the work that has been and will be carried out by someone. Performance can be defined as an individual's success in doing his job. To be able to assess the employee's performance in an objective and accurate, employers must be able to measure the performance levels of their 
employees. Intanghina (2009) cites the opinion of Mitchel provide indicators to measure employee the performance. Indicators provided by Mitchel is as follows: Quality of Work, Job Knowledge, creativeness, Cooperation, Dependability, Initiative, Personal qualities, Capability, Communication. The measurement means providing opportunities for employees to know their performance. Performance measurement can also serve as an attempt to gather the information that can be used to guide employees through a series of specific priority.

Improved performance in itself is not an easy thing. The company's management is often difficult to identify what is causing the employee's performance declined. This is due to the complexity of the causes of a decrease in employee performance. Additionally, sometimes not the same as the cause of a decrease in the performance of an employee by another employee. Although the company's management has provided clear measurement tools to measure performance, still does not guarantee that the results obtained can be accurate to improved performance in the future. That situation does not mean that upgrading the performance cannot be pursued by management company performance good employee can affect the overall performance of the organization. It required special attention to make efforts to improve employee performance. Not only this, but the company must also consider factors that inhibit employees so that it can lead to decreased employee performance. One of the factors that lead to decreased employee performance is their work demands and workloads can result in stress on employees.

Competition and higher professionalism demands cause many pressures to be faced individual in a work environment. In addition to the pressure that comes from the work environment, family environment and the social environment is also very potentially cause anxiety. The detrimental impact of their anxiety disorder that is often experienced by the public and the employees, especially the so-called stress. Stress can contribute positively to the performance and also play a negative role, as described in "Yerkes Dodson Law (1904) which states the relationship between stress and performance inverted U-shaped". (Mas'ud, 2002: 20), Sasono (2004: 5) reveal that stress has positive and negative effects. The positive impact of stress at a low level to a moderate level functional in the sense of acting as drivers of employee performance improvement. While the negative impact of a high level of stress is a decrease in employee performance drastically.

Job stress is an important aspect for companies particularly in connection with the performance of employees. Companies must have a performance, good performance/high can help companies gain. Conversely, if the decline could hurt the company's performance. Therefore, the performance of employees needs to gain attention among others, by the way, do studies related to job stress variables.

The interaction of employees with work and the work environment generating services. Based on their performance, the employees get rewards that have an impact on performance. As the results or other results of the work, employees can experience stress, which can progress to make employees ill, physically and mentally, so it can no longer work optimally (Munandar, 2008: 371).

High demands on employees can increase the level of stress in his job. According to Gibson and Ivancevich (2001: 280-281), the stress in the optimum appearance is a positive stress condition because it can encourage employees to work at a higher level, while the stress of too little and too much of a burden is negative stress conditions as it 
may cause the declining performance of the employees. The emergence of stress, whether caused by something fun or something unpleasant will give a certain result on a person. Ultimately this leads to an increase in professionalism in the management of human resources for the company still exists and more productive. Therefore, companies should be able to keep, maintain and develop human resources (labor) that are within the company. According to Wright (2006) Human Resource Management effective resource aimed at improving corporate performance by giving satisfaction to employees, customers, innovation, and productivity so that the right human resource management is very important in an organization/company.

At Aronson research and Goransson (1999) can be seen that the stressors of work disliked making employees experiencing work stress. The gap between the demands of work with existing resources (work stress), makes people feel more negative affect and life dissatisfaction. In other words, work stress can reduce wellbeing. Wellbeing is an important aspect of quality of life or mental health of an individual (Page and VelaBrodrick, 2009; Keyes, 2006). Aronsson research and Goransson (1999) based on Statistics' Swedish Labor Market Surveys $(N=1,564)$ showed that there were $28 \%$ of permanent employees who do not like his job.

Work stress, according to David and Newstrom (2008) as a condition that affects the emotions, thought processes, and physical condition. Work stress to a certain extent is a trigger factor improving employee performance but if already past that point, the presence of job stress would likely trigger the issue which will certainly affect the performance or performance. Results of research and Ramzan Ahmed (2013) prove that work stress has a significant effect on employee performance. The research result Zafar et al. (2015) also shows that work stress has a significant effect on employee performance. The results of the Gaffar Hulaifah (2012) proved that positive work stress having an effect on performance. Lizhen Jing (2008) work stress has a significant effect on performance. Likewise, the results of research Yulia Anggraini (2008) prove that work stress affects the performance of the salesman. However, the research results May Yung Leung, et al. (2011) prove the work stress has a negative correlation to the performance of employees. As well as results of research Rubina Hanif, et al. (2011) which states that stress negatively related to the performance of teachers. Halida research results Savira (2010) also shows that job stress negatively affect performance. Adnan research results Enhassi, et al. (2015) explained that the demands of work and the demands of the task at construction workers in Gaza track do not affect the performance of employees. Other findings that the construction workers have emotional stress and fatigue which affects the performance of employees. (2011) prove the work stress has a negative correlation to the performance of employees. As well as results of research Rubina Hanif, et al. (2011) which states that stress negatively related to the performance of teachers. Halida research results Savira (2010) also shows that job stress negatively affect performance. Adnan research results Enhassi, et al. (2015) explained that the demands of work and the demands of the task at construction workers in Gaza track do not affect the performance of employees. Other findings that the construction workers have emotional stress and fatigue which affects the performance of employees. (2011) prove the work stress has a negative correlation to the performance of employees. As well as results of research Rubina Hanif, et al. (2011) which states that stress negatively related to the performance of teachers. Halida research results Savira (2010) also shows that job stress negatively affect performance. Adnan research results Enhassi, et al. (2015) explained that the demands of work and the 
demands of the task at construction workers in Gaza track do not affect the performance of employees. Other findings that the construction workers have emotional stress and fatigue which affects the performance of employees. Halida research results Savira (2010) also shows that job stress negatively affect performance. Adnan research results Enhassi, et al. (2015) explained that the demands of work and the demands of the task at construction workers in Gaza track do not affect the performance of employees. Other findings that the construction workers have emotional stress and fatigue which affects the performance of employees. Halida research results Savira (2010) also shows that job stress negatively affect performance. Adnan research results Enhassi, et al. (2015) explained that the demands of work and the demands of the task at construction workers in Gaza track do not affect the performance of employees. Other findings that the construction workers have emotional stress and fatigue which affects the performance of employees.

Robbins (2007: 368) defines job stress as a dynamic condition in which a person is confronted with the opportunities, barriers, or demand related to what they want and for that success was not certain. The research result Malek (2010) showed that work stress have a significant effect on the psychological well-being as the opinion of Warr (in Dwipayama, 2010) that the psychological well-being is a concept associated with what is perceived individuals on its activities in daily life ,

Ryff (in Dwipayama 2010) argues that the psychological well-being is a condition of a person who has the ability to accept yourself and life in the past (self-acceptance), development or personal growth (personal growth), the belief that his life meaningful and purposeful (purpose in life), has the quality of a positive relationship with others (positive relationship with others), the capacity to regulate effectively the life and the environment (environmental mastery), and the ability to determine their own actions (autonomy). People who have psychological well-being is good is people who are able to realize her potential continuously, and accept themselves as they are, are able to form warm relationships with others, have the independence to social pressures, has a meaning in life,

Veenhouven (in Diener, 1994) explains that subjective well-being is the level at which someone is judging the quality of life as something that is expected and feel unpleasant emotions. As As'ad opinion (1987: 47) that the important driving factors that cause humans to work is the need to be met. Activities in the work contains elements of a social activity, producing things, and ultimately aims to meet their needs and also aims to achieve better living standards. This indicates that the employee's performance is influenced by subjective well-being.

The results of the study the effect of work stress on employee performance through the psychological well-being and subjective well-being show inconsistent results or the research gap, on May research Yung Leung, et al. (2011), Rubina Hanif, et al. (2011), halides Savira (2010) proved that the negative effect of job stress, while research Lizhen Jing (2008), Hulaifah Gaffar (2012) showed that job stress positive effect on performance, but the results Adnan Enhassi, et al. (2015) prove that work stress does not affect the performance, the research is done now to develop job stress directly affects the performance (in May Yung Leung, et al. (2011), Rubina Hanif et al., (2011), halides Savira ( 2010), Lizhen Jing (2008), Hulailfah, Gaffar, (2012) and Adnan Enhassi et al (2015), as mediation work stress has been studied still partial, stress influence psychological well being; work stress affects the subjective well-beingto analyze the 
effect of work stress on employee performance, analyze the effect of work stress on psychological well-being, to analyze the influence of psychological well-being of the employee's performance, analyze the effect of work stress on subjective well-being, to analyze the influence of subjective well-being on employee performance, To psychological analyze the influence of well-being as mediation work stress on employee performance, and analyze the influence of subjective well-being as mediation work stress on employee performance

\section{METHODS}

The method used must be a method that can actually answer the research problems. This type of research is explanatory research with survey approach. This study seeks to explain the causal relationship between the variables and their effects through hypothesis testing (Sugiyono, 2010).

The population in this study were all employees of PT. Insight Global Top Bali area, with a minimum term of one year, amounting to 78 people. Furthermore, all members of the population of respondents to the study (study census). Reasons take employees with a minimum term of one year from assessing the performance of employees will be started performing when a minimum service life of 1 year.

The structure of the existing relationship on all four variables will be analyzed using SEMPLS models. Why use Partial Least Square (PLS) is there some research hypotheses that do not have a solid theoretical basis. PLS can be used to test the causal relationship the variables that have not received much support the theory or the study is exploratory (Ghostly, 2011). Another reason is the PLS is able to analyze the constructs with reflective and formative indicators (Hair, 2010). PLS is a powerful analytical method, because not based on many assumptions, data should not be the normal distribution, the sample should not be large, and is able to explain the relationship between latent variables (Ghostly, 2011). Another advantage of PLS is that it can be used on the data with different types of scale, being able to manage the problem of multicollinearity between the independent variables, and the results remain solid (Robust) although there are data that are not normal and missing (Hartono, 2009).

\section{RESULT}

Data were obtained from questionnaires distributed to respondents. A sample of respondents in these study as many as 78 employees of PT. Insight Global Top Bali area. As a general overview of gender, education and long work presented in presented in Table 1 below:

\begin{tabular}{lc}
\hline Characteristics & Percentage (\%) \\
Gender & 65.4 \\
\hline Man & 34.6 \\
woman & \\
Education & 17.9 \\
High School & 44.9 \\
Diploma & 26.9 \\
S1 & 10.3 \\
S2 &
\end{tabular}




\begin{tabular}{ll}
\hline Length of work & \\
1 to 3 years & 15.4 \\
3.1 to 5 years & 33.3 \\
More than 5 years & 51.3 \\
\hline
\end{tabular}

\section{Table 1. Description Respondents}

\section{Data analysis}

Model PLS has two parts, namely the measurement model (outer model) and structural models (inner model) and processed by the score indicator. Testing measurement model (measurement model) in this study aims to evaluate the indicators that are reflective of the construct. Analysis of indicators - indicators used is tested in order to give meaning to the contributions made by the latent variables. The empirical analysis aimed to validate the model and the reliability of the constructs that reflect the parameters of the latent variables or constructs that are built based on theory and empirical studies. This study uses five latent variables namely job stress, psychological well-being, subjective well-being and performance of employees with a reflective indicator.

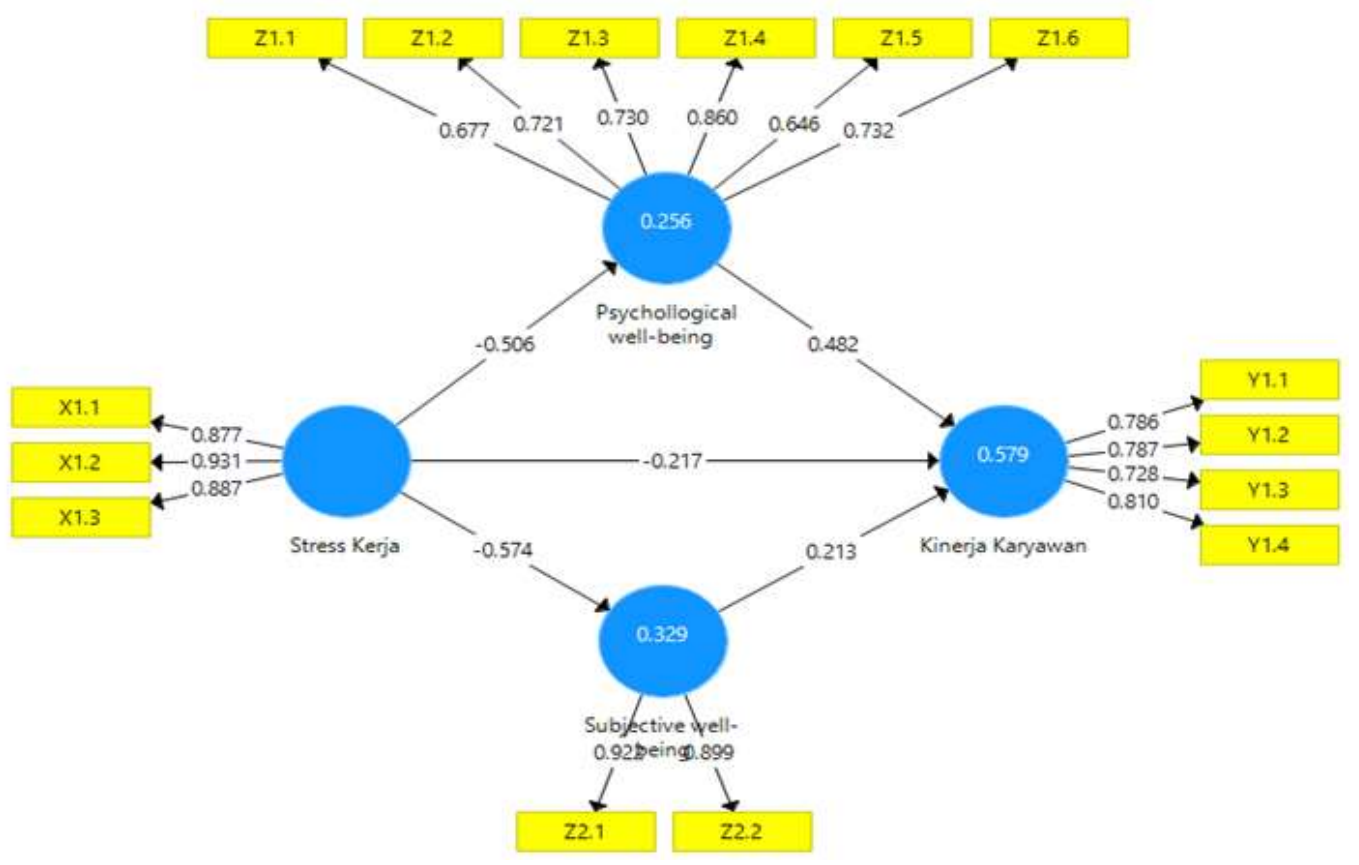

Figure 1

Model Test Results Hypothesis

Result analysis hypothetical model the combined effect of work stress on psychological well-being was $25.6 \%$. The combined effect of work stress on subjective well-being is $32.9 \%$. While the effect of work stress, psychological well-being and psychological wellbeing of the performance was $57.9 \%$. Hair et. al. (2014) states that the contribution to the value of between $20 \%-50 \%$ included in the category is quite high. 
Ekromi Fraida Tsalasah, et al.

\begin{tabular}{|c|c|c|c|c|}
\hline Relationship between Variables & $\begin{array}{c}\text { Original } \\
\text { Sample (O) }\end{array}$ & $\begin{array}{l}\text { Standard } \\
\text { Deviation } \\
\text { (STDEV) }\end{array}$ & $\begin{array}{l}\text { T Statistics } \\
(\mid \text { O / STDEV } \\
\mid)\end{array}$ & $\mathrm{P}$ \\
\hline $\begin{array}{l}\text { Psychological well-being, } \mathbf{R 2}=\mathbf{2 5 . 6 \%} \\
\text { work stress ? Psychollogical well- } \\
\text { being }\end{array}$ & -0.506 & 0,067 & 7.601 & 0,000 \\
\hline $\begin{array}{l}\text { Subjective well-being, } \mathbf{R 2}=32.9 \% \\
\text { work stress [ Subjective well-being }\end{array}$ & -0.574 & 0,071 & 8.054 & 0,000 \\
\hline $\begin{array}{l}\text { Employee performance, } \mathbf{R} \mathbf{2}=\mathbf{5 7 . 9} \% \\
\text { work stress }\end{array}$ & -0.217 & 0.099 & 2,181 & 0,030 \\
\hline $\begin{array}{l}\text { Psychological well-being } \text { employee } \\
\text { performance }\end{array}$ & 0,482 & 0.102 & 4.717 & 0,000 \\
\hline $\begin{array}{l}\text { Subjective well-being ? employee } \\
\text { performance }\end{array}$ & .213 & .101 & 2,113 & 0,035 \\
\hline
\end{tabular}

Source: Data processed, 2018.

The coefficient of the direct effect of work stress on psychological well-being is significant $(\beta=-0.506 ; p=0.000)$. Indicators of whole work stress have a positive coefficient and reflective. The coefficient of the direct effect of work stress on subjective well-being is significant $(\beta=-0.574 ; p=0.000)$. The coefficient of the direct effect of work stress on employee performance is significant $(\beta=-0.217 ; p=0.030)$. Psychological coefficient direct influence on the well-being of the employee's performance is significant $(\beta=0.482 ; p=0.000)$. The coefficient of the direct influence of the subjective well-being of the employee's performance is significant $(\beta=0.213 ; p=$ $0.035)$.

Table 3. Indirect Influence Test Results

\begin{tabular}{lccc}
\hline Relationship between Variables & Coefficient & $\mathrm{P}$ & Status \\
\hline $\begin{array}{l}\text { Work stress -> Psychollogical well-being -> } \\
\text { employee performance }\end{array}$ & -0.244 & 0,000 & Significant \\
$\begin{array}{l}\text { Work stress -> Subjective well-being -> } \\
\text { employee performance }\end{array}$ & -0.122 & 0,042 & Significant \\
\hline
\end{tabular}

Source: Data processed, 2018.

In the hypothetical model, there are two indirect influences. First, the indirect effect of work stress on employee performance through psychological well-being of $-0.506 \mathrm{x}$ $0.482=-0.244$. Second, the indirect effect of work stress on employee performance through the subjective well-being of $-0.574 \times 0.213=0.122$. Both the indirect effect is significant because all the coefficient paths through mediating variables tested significantly $(p<0.05)$.

\section{Hypothesis Testing}

In this study, there are 7 hypotheses, in which the five major direct influence hypothesis test and 2 test hypotheses large indirect effect. Hypothesis $\mathrm{H} 1$ states that work stress affects the performance of employees. The direct effect on the relationship of work stress on employee performance of -0.217 with $p$-value of $0.030(p<0.05)$ were significant. Stress can be an explanatory work performance, so H1 supported. 
Hypothesis $\mathrm{H}_{2}$ states that work stress affect the well-being Psychological. The direct effect on job stress related to the psychological well-being of -0.506 with as big as a pvalue of $0.000(p<0.05)$ were significant. Work stress can be a determinant psychological well-being so that $\mathrm{H}_{2}$ is supported.

$\mathrm{H}_{3}$ hypothesis states that Psychological well-being affects the performance of employees. Direct influence on the well-being Psychological relation to the performance of employees is 0,482 with a $p$-value of $0.000(p<0.05)$ were significant. Psychological well-being can be a determinant of the performance of employees, so $\mathrm{H}_{3}$ is supported.

$\mathrm{H}_{4}$ hypothesis states that work stress affects Subjective well-being. Direct influence on work stress on Subjective well-being of 0.574 with a $p$-value of $0.000(p<0.05)$ were significant. Work stress can be a determinant subjective well-being, so $\mathrm{H}_{4}$ is supported.

$\mathrm{H} 5$ hypothesis states that subjective well-being affects the performance of employees. The direct effect on subjective well-being on the performance of employees is 0.213 with the value of the company amounted to 0.035 ( $p<0.05)$ were significant. Subjective wellbeing can be explanatory employee performance, so $\mathrm{H}_{5}$ is supported.

H6 states that Psychological well-being as a mediating variable between job stress and employee performance. The indirect effect on the relationship of work stress on employee performance through Psychological well-being of -0.244 with the ap value of 0.000 is significant. Psychological well-being shown to mediate the effect of work stress on employee performance, so that $\mathrm{H} 6$ is supported.

$\mathrm{H} 7$ stated that subjective well-being as a mediating variable between job stress and employee performance. The indirect effect on the relationship of work stress on employee performance through subjective well-being of -0.122 with $p$ value of 0.042 is significant. Subjective well-being shown to mediate the effect of stress on employee performance, so $\mathrm{H} 7$ supported.

\section{DISCUSSION}

\section{Effect of Effect of Job Stress on Employee Performance}

The results showed that job stress count of 2.181 with significance of $0,030 t$, for $t>t$ table $(2,181>2,000)$ or the significance of $t<5 \%(0.000<0.05)$, the occupational stress is partially a significant effect on the performance of employees. Because of the path, the coefficient is negative $(-0.217)$ indicates the effect of both is negative or opposite directions, so that $\mathrm{H} 1$ is accepted or significant. This means that the higher job stress leads to lower employee performance. Research results and Ramzan Ahmed (2013), Zafar, et al. (2015), Leung, et al. (2011), Malek (2010), S. Lamb, et al. (2016), Hanif, et al. (2011), Gaffar (2012), Jing (2008), Anggraini (2008), Savira (2010), Robbins (2007) prove that work stress affect the performance of employees. Stress according to Kreitner and Knicks (2005: 351) as an adaptive response characteristic and are connected by an individual or psychological process, which is a consequence of any external action, situation, or event that puts the demands of psychological/physical special someone. The findings of this study indicate that the stress of work is reflected from the stress of employees in the category of low views of respondents do not have excessive workloads, work schedules are not solid or without a pause, do not get bored with the routine of daily work, do not get in trouble at work, care for the working group and have a good relationship with co-workers, so as to improve employee performance. This

102 Management and Economics Journal (MEC-J)

Vol 3 (1) April 2019 
shows that the employees' workload is felt not heavy so it can improve the performance of employees.

\section{Effect of Job Stress on Psychological Well-being}

The results showed that job stress count of 7.601 with a significance of $0.000 t$, for $t>t$ table $(7.601>2.000)$ or the significance of $t<5 \%(0.000<0.05)$, the partially significant effect on job stress Psychological Well-being, Because the path coefficient is negative (0.506) indicates the effect of both is negative or opposite directions, so that $\mathrm{H} 2$ is accepted or significant. This means that the higher the job stress lead to lower psychological well-being. The research result Malek (2010), Warr (2010), Robbins (2007) prove that work stress affect the well-being Psychological. Employee stress levels low employment can increase Psychological the well-being that is reflected from the open to accept criticism, always optimistic in the work, trying to develop themselves in completing the work, continue to explore the potential of self, confident where employees are meaningful to others, have a purpose in life obviously, always maintain good relations with colleagues foster good relationships with superiors, able to set the rhythm private life effectively, is not easily affected by the surrounding environment, is able to act quickly to solve the problems and is able to work independently.

\section{Well-Being Psychological influence on Employee Performance}

The results showed that psychological well-being $t$-count amounted to 4.717 with a significance of $0.000 t$, for $t>t$ table $(4.717>2.000)$ or the significance of $t<5 \%(0.000$ $<0.05$ ), the partially psychological well-being have a significant effect to employee performance, Because the path coefficient is positive (0.482) indicates the effect of both positive or unidirectional, so $\mathrm{H}_{3}$ is accepted or significant. This means that the higher psychological well-being lead to higher employee performance. as outlook Ryff (in Dwipayama, 2010) that the psychological well-being is a condition of a person who has the ability to accept yourself and life in the past (self-acceptance), development or personal growth (personal growth), the belief that his life meaningful and purposeful ( purpose in life), has the quality of a positive relationship with others (positive relationship with others), the capacity to regulate effectively the life and the environment (environmental mastery), and the ability to determine their own actions (autonomy). People who have psychological well-being is good are people who are able to realize her potential continuously, and accept themselves as they are, are able to form warm relationships with others, have the independence to social pressures has a meaning in life, and able to control the external environment, which means the higher psychological well-being can improve employee performance. The results of the study Huang, et al. (2016), Ryff (2010) proved that psychological well-being affect the performance of employees.

\section{Working Against Stress Effect of Subjective Well-Being}

The results showed that job stress $t$-count of 8.054 with a significance of $0.000 t$, for $t>t$ table $(8.054>2.000)$ or the significance of $t<5 \%(0.000<0.05)$, the partially significant effect on job stress Subjective Well-being, Because the path coefficient is negative (0.574 ) indicates the effect of both is negative or opposite directions so that the $\mathrm{H}_{4}$ is accepted or significant. This means that the higher the job stress leads to lower subjective well-being. The results of this study are consistent with studies Kris (2008), Diener and Scollon (2003) which states that the work stress affects the Subjective wellbeing. As Veenhouven view (in Diener, 1994) that subjective well-being is the level at 
which someone is judging the quality of life as something that is expected and feels unpleasant emotions. The findings of this study indicate that employees with low-stress levels can improve the subjective well-being in terms of affective and cognitive reflected from always being kind to the co-worker and able to withstand the emotions and be able to do the tasks in a rational and always trying to improve.

\section{Effect of Subjective Well-Being on Employee Performance}

The results showed that subjective well-being $t$-count amounted to 2.113 with a significance of $0.035 \mathrm{t}$, for $\mathrm{t}>\mathrm{t}$ table $(2,113>2,000)$ or the significance of $t<5 \%(0.035$ $<0.05$ ), the partially subjective well-being have a significant effect on employee performance, Because the path coefficient is positive (0.213) indicates the effect of both positive or unidirectional, so $\mathrm{H}_{5}$ is received or significant. This means that the higher subjective well-being lead to higher employee performance. The results support the studies of Huang, et al. (2016), Ryff (2010), Robbins (2007), Diener (1994) states that the Subjective well-being affects the performance of employees. Subjective well-being showed life satisfaction and evaluation of the domains of life essentials such as employment, health, and relationships. Also included their emotions, such as excitement and involvement, and experience negative emotions, such as anger, sadness, and fear that a little. In other words, happiness is the name given to thoughts and positive feelings towards a person's life (Diener, 2008).

\section{Psychological influence well-being as a mediating variable between job stress and employee performance}

Psychological well-being is able to mediate the effect of work stress on employee performance. If an employee feels stress at work and are not supported by good physical health, of course, will lead to job be no focus on work, this will have an impact that the decline in the performance of employees. Therefore, it has psychological wellbeing of high becomes important, because it can improve the performance of employees. Psychological well-being is an individual ability to accept his situation, establish a warm relationship with others, are able to control themselves and independent of social pressure, and be able to realize their potential that has meaning in his life. As the view of David and Newstrom (2008) defines job stress as a condition that affects the emotions, thought processes, and physical condition. According to Warr (in Dwipayama, 2010) Psychological Well Being is a concept that relates to what people perceived in their activities in daily life. The results of the study Huang, et al. (2016), Ryff (2010) found that psychological well-being affects performance. One activity was manifested in movements called work. Working connotes a task ends with the work that can be enjoyed by humans are concerned. Important driving factors that cause humans to work are the need to be met. Activities in the work contain elements of social activity, producing things, and ultimately aims to meet their needs and also aims to achieve better living standards (As'ad, 1987: 47).

\section{Effect of Subjective well-being as a mediating variable between job stress and employee performance}

Subjective well-being is able to mediate the effect of work stress on employee performance. This indicates that the level of stress experienced relatively moderate and perceived work routines. Employee performance can be improved if the employee has subjective well-being is high. These results indicate although there are conditions that trigger stress because of subjective well-being can increase employee performance. As 
the view Robbins (2007: 368) that the work stress as a dynamic condition in which a person is confronted with the opportunities, barriers, or demand related to what they want and for that success was not certain. Subjective well-being is part of happiness, the term happiness and subjective well-being are also often used interchangeably (Diener \& Bisswas, 2008). Performance is a set of results and refers to the achievement of the actions and the implementation of the work requested something (Stolovitch and Keeps: 1992). The results support the studies of Huang, et al. (2016), Ryff (2010), Robbins (2007),

\section{CONCLUSIONS}

In accordance with the analysis results related Effect of Job Stress on Employee Performance through Psychological Well-Being and Subjective Well-Being, the researchers can make some conclusions as follows.

Work stress affects the performance of employees, this shows that the workload of the employees perceived to be heavy so it can improve the performance of employees.

Psychological work stress affects well-being, which means that the lower the stress of employees can improve psychological wellbeing. Employees who have the Psychological Well Being good is the employees who are able to realize the potential of themselves continuously, and accept themselves as they are, were able to establish warm relations with others, have the independence to social pressures, has a meaning in life, and be able to control the external environment.

Psychological well-being affects the performance of employees, which means that the higher the psychological well-being leads to higher employee performance. Employees who have psychological well-being that both are employees who are able to realize the potential of themselves continuously, and accept themselves as they are, were able to establish warm relations with others, have the independence to social pressures, has a meaning in life, and be able to control the external environment, which means the higher psychological well-being can improve employee performance

Work stress affects subjective well-being, which means that the lower the stress of employees may increase subjective wellbeing. Employees with low stress levels can improve the subjective well-being in terms of effective and cognitive reflected from always being kind to the co-worker and able to withstand the emotions and be able to do the tasks in a rational and always trying to improve.

Subjective well-being affects the performance of employees, which means that the higher subjective well-being leads to higher employee performance. Subjective wellbeing showed life satisfaction and evaluation of the domains of life essentials such as employment, health, and relationships.

Psychological well-being able to mediate the effect of work stress on employee performance. If an employee feels stress at work and are not supported by good physical health, of course, will lead to job be no focus on work, this will have an impact that the decline in the performance of employees. Employee performance can be enhanced if employees have psychological stay high well-being.

Subjective well-being is able to mediate the effect of work stress on employee performance. This indicates that the level of stress experienced relatively moderate and 
perceived as a routine job. Employee performance can be improved if the employee has a subjective well-being is high.

\section{REFERENCES}

Adnan Enshassi, et al. 2015. Job stress, job burn out and safety performance in the Palestinian Construction Industry. Journal of Financial Management of Property and Construction.

Ahmed dan Ramzan. 2013. Effects of Job Stress on Employees Job Performance A Study on Banking Sector of Pakistan. Journal of Business and Management (IOSR-JBM). Volume 11, Issue 6.

As'ad, 1987. Psikologi Industri. Yogyakarta: Liberty.

Davis, Keith dan Newstrom, John W. 2008. Perilaku Dalam Organisasi. Edisi ke Tujuh. Jakarta: Erlangga.

Diener E. 1999. Subjective well-being: three decades of Progress. Psychological Bulletin $125,2.276-302$

Diener, E. 1984. Subjective well-being. Psychological Bulletin. 95, 542-575.

Diener, E. 1994. Assessing subjective well-being: Progress and opportunities. Social Indicators Research, 31, 103-157. (2005 reprinted in Citation classics from Social Indicators Research)

Diener, E., \& Ryan, K. 2009. Subjective well-being: a general overview. South African Journal of Psychology, 39(4), 391-406.

Diener, Ed Oishi,Shigehiro \& Lucas Richard E. 2000. Personality, Culture, and Subjective Well-Being: Emotional and Cognitive Evaluations of Life Annu. Rev. Psychol. 54:403-25 Diener, Ed. \& Biswas-Diener, R. 2008. Happiness: Unlocking the Mysteries of Psychological Wealth. Singapore: Blackwell Publishing.

Dwipayama, Yudhistira. 2010. Gambaran kepribadian dan psyhologiall wellbeing ditinjau berdasarkan golongan darah. Universitas Psikologi Tarumanegara. Bandung.

Ghozali, Imam. 2011. Aplikasi Analisis Multivariate Dengan Program SPSS. Semarang: Badan Penerbit Universitas Diponegoro.

Gibson, James L, John M. Ivancevich dan James H. Donnelly Jr, 2001. Organizations: Behaviour, Structure and Process, McGraw-Hill Companies Inc, Boston.

Hulaifah Gaffar. 2012. Pengaruh stress kerja Terhadap Kinerja Karyawan pada PT. Bank Mandiri (Persero), Tbk. Kantor Wilayah X Makasar.

Intanghina. 2009. Pengaruh Budayaya Perusahaan dan Lingkungan Kerja terhadap Kinerja Karyawan (serial online), 28 April. Availabel from: URL: http://intaqnghina.wordpress.com/2008/04/28/pengaruh-budayaperusahaan -danlingkungan-kerja-terhadap-kinerja -karyawan

Lamb, S. et al. 2016. A longitudinal investigation of work environment stressors on the performance and wellbeing of office workers.

Liang Chi Huang, et al. 2016. High Performance Work System, Employee Well-Being, and Job involvement: an empirical studi.

Lizhen Jing. 2008. Faculty's Job Stress and performance in the undergraduate education assessment in China: A mixed-methods study).

Mas'ud, Fuad. 2002. 40 Mitos Manajemen Sumber Daya Manusia. Semarang: Badan Penerbit Universitas Diponegoro.

Mei Yung Leung, et al. 2011. Structural Linear Relationships between Job Stress, Burnout, Phsycological Stress, and Performance of Construction Project Managers.

Mohd. Dahlan A. Malek. 2010. Stress and Psychological Well-being in UK and Malaysian Fire Fighters. 
Munandar Ashar Sunyoto. 2008. Psikologi Industri dan Organisasi. Jakarta: Universitas Indonesia.

Rivai, Veithzal. 2005. Manajemen Sumber Daya Manusia untuk Perusahaan Dari Teori ke Praktik, Edisi Pertama, Cetakan Kedua, PT. Raja Grafindo Persada, Jakarta.

Robbins, Stephen P. 2003. Organiational Behavior (Fifth Edition). New Jersey: Pearson Education Inc

Robbins, Stephen P. 2007. Organiational Behavior (Twelfth Edition). New Jersey: Pearson Education Inc.

Rubina Hanif, et al. 2011. Personal and Job related Predictors of Teacher stress and Job Performance among School Teachers.

Sasono, Eko. 2004. Mengelola Stres Kerja. Jurnal Fokus Ekonomi. Vol III. No.2.

Savira, Halida. 2010. Pengaruh stress kerja dan Locus of Control terhadap kepuasan kerja dan kinerja pegawai bagian layanan PT. Bank Negara Indonesia (Persero), TBK. Cabang Malang. Jurnal Aplikasi Manajemen. Vol 12. No.1.

Stolovitch, Harold D., and Keeps, Erica J., 1992, Handbook of Human Performance Technology A Comprehensive Guide for Analysis and Solving Performance Problem in Organizations. San Francisco: Jersey-Bass Publisher

Sugiyono, 2008. Metode Penelitian Kunatitatif Kualitatif dan R\&D. Bandung Alfabeta.

Umam, Khaerul. 2010. Perilaku Organisasi. CV. Cetakan 1. Bandung: Pustaka Setia. Bandung.

Yulia Anggraini. 2008. Pengaruh sumber stress kerja dan motivasi terhadap kinerja pramuniaga (Studi pada PT. Sarinah (Persero) Malang dan PT. Ratu Idaman Pratama Malang).

Zafar, Qadoos, Ayesha Ali, Tayyab Hameed,, Toqeer Ilyas, Hafiz Imran Younas. 2015. The Influence of Job Stress on Employees Performance in Pakistan. American Journal of Social Science Research. Vol. 1, No. 4, 2015, pp. 221-225. 